\title{
RENAŞTEREA GNOZEI PĂGÂNE ÎN ROMÂNIA - UN MARE PERICOL PENTRU TINERETUL ORTODOX
}

\author{
Gheorghe Istodor*
}

\begin{abstract}
The pagan, occult and esoteric gnosis, promoted by $A G E A C$ association, is an example of neo-paganism implemented during the postmodern period. It is a proof of the cruel reality represented by the phenomenon of the nowadays de christianisation. AGEAC proposes a pseudo- education and a pseudo- psychology which they call revolutionary psychology and which contributes, according to them, to the creation of a new man, gnostic, esoteric, occult and pagan. The pagan gnosis proposed by AGEAC is a return to the oriental pseudo- spirituality. The anti-educational and anti-psychological elements concern particularly the consciousness and the dimension of reality and are part of a manipulation program that turn the recruited person completely, to these adding the demonizing of all religious, philosophical, scientific, psychological and cultural values of both the Church and the contemporary society. AGEAC remains a tantric sect, with clear elements of demonology and black magic, which introduces the adept into a fantasy world of alienation and total degeneration. At the same time, it proposes a cult of the elected in the person of Samael Aun Weor, as rarely meets in the area of sect and pathologic manifestations.
\end{abstract}

Keywords: Samael Aun Weor, AGEAC, pagan gnosis, esoteric, occult, tantra yoga, black magic, demonology, psychology revolutionary neo-paganism

\section{Preliminarii}

Neo-păgânismul reprezintă o mişcare nocivă ce-şi propune reînvierea vechilor concepţii ancestrale ale omului separat de Dumnezeu prin păcat şi care încearcă o substituire a creştinismului cu aceste valori începând cu Renaşterea modernă. În cadrul neopăgânismului actual de desacralizare şi decreştinare, amândouă fiind dimensiuni amplu numit secularizare. Neo-păgânismul a reprezentat contextul fertil pentru renaşterea gnozei păgâne, astfel vorbim despre

* PhD, Rev. Professor, Faculty of Orthodox Theology at Ovidius University, Constanta, Romania. 
o neo-gnoză care are pretenţii de religiozitate şi care propune omului decreştinat şi secularizat de azi statutul de supraom, de iluminat de apartenenţă la elita societăţii actuale. Acest demers presupune însă negarea tuturor componentelor religioase, filosofice, ştiinţifice, educaţionale, psihologice, sociologice şi culturale pe care le are actuala societate secularizată şi întoarcerea omului contemporan la vechile concepţii păgâne ante şi anti-creştine, de sorginte orientală sau occidentală. Aşadar, în cadrul neo-gnozei păgâne din zilele noastre, ocultismul şi esoterismul reprezintă cei doi piloni în jurul cărora se asamblează în mod sincretism actuala gnoză păgână. Din nefericire, renaşterea gnozei păgâne esoteric-ocultă nu a ocolit România, de aceea evaluarea misionară a acesteia trebuie să plece de la înţelegerea identităţii lui Samael Aum Weor şi a asociaţiei gnostice AGEAC.

Pe site-urile de propagandă a AGEAC, Victor Emanuel Gomez Rodriguez, cetăţean columbian şi apoi mexican, născut la Bogota în anul 1917 şi-a luat supra-numele de Samael Aum Weor ce înseamnă Verb divin, conform tradiţiei kabalistice fonetice, dar şi Justiţia lui Dumnezeu conform ortodoxiei textelor ebraice. De la început observăm o imitaţie a Mântuitorului numit pe drept cuvânt Logosul dumnezeiesc în Evanghelia Sfântului Ioan Teologul, o imitaţie care este de fapt o reincarnare a Mântuitorului dar şi al altor iluminaţi şi maeştri precum Albert cel Mare, Faust, Apollonius sdin Tyana, Hermes Trismegistul sau Zoroaztru. Prezentarea este un delir mistic, Samael fiind văzut ca un fulger în mijlocul furtunii, ca un erou solar sau ca o piatră filosofică vie care se reîncarnează la câteva mii de ani să aducă oamenilor misterioase forţe eleatrice, spermatice şi ignice şi totodată mesaje noi şi incontestabile conţinând cele mai exaltate secrete ale Cosmosului şi ale locuinţelor enigmatice ale fiilor focului. A străbătut vieţi şi ţări purtând în buzunarele sale rețete alchimice şi simboluri care mai târziu se vor transforma în tratate de sexologie transcendentală de medicină naturală, de psihologie orientală, de astrologie şi sociologie niciodată revelate până acum. El ar fi un om supra normal, un Elohim, un avatar al Varsătorului - 
reconfirmă lucrarea lui Iisus prezentat ca avatar al Peştilor - un supraom, un venerabil maestru al ordinului Sfântului Ian care s-ar fi dezîncarnat în anul 1977, dar s-a arătat în continuare la discipolii săi utilizând culoare hiperdimensională sau universuri paralele pentru a continua să transmită mesajul său. Are pretenţia de atotştiinţă şi omniprezenţă, prezentându-se a fi

\begin{abstract}
„Buddha Maytreya Kalki Avatara al Noii Ere a Vărsătorului. El 1-ar ajuta pe om să-şi restaureze natura sa divină, să-şi cunoască sensul absolut al existenţei, să restabilească adevărata religiozitate prin suprimarea falsei religiozităţi ce a fost instituită de falşi 'salvatori' înceşmântaţi în interpretarea literală şi oarbă a textelor religioase ce a avut ca consecinţă conducerea enoriaşilor la foamete, mizerie, disperare şi moarte. El reabilitează şi adevărata ştiinţă scrutând materia, antimateria, sorii, lunile, glacile, scoţând la iveală nenumărate secrete ignorate de pedanţi fizicieni, chimişti, matematicieni, astronauţi, logicieni sau biologi”.
\end{abstract}

Cadrul propagării acestor concepţii delirante îl constituie AGEAC sau Asociaţia Geofilosofică de Studii Antropologice şi Culturale care pretinde a fi o instituţie umanistică, filosofică şi antropologică a cărei raţiune de a fi este aceea de a investi în valorile culturale, incorporale în tradiţiile, folclorul, mitologia, filosofia, arta şi credinţele tuturor popoarelor antichităţii cu scopul de a extrage din acestea principiile şi valorile ce promit omului modern să trăiască într-un mod conştient şi inteligent. A fost fondată în Spania în anul 1989 şi este o organizaţie internaţională cu filiale în 40 de ţări de pe cinci continente. Pretinde a nu fi o religie ci o instituţie culturală fundamentală pe respectul faţă de liberul arbitru al persoanelor ! Scopul acestei organizaţii ilegale - care nu plăteşte taxe statului român ar fi să investigheze şi să împărtăşească cu semenii înţelepciunea universală a tuturor timpurilor care i-ar permite omului să aibă o viziune mai umană, mai conştientă şi mai transcendentă.

Pentru manipularea şi îndobitocirea elor naivi, celor necatehizaţi dintre români, se lupă două asociaţii aşa-zis gnostice: 
AGEAC şi VOPUS ${ }^{1}$. În realitate, se desfăşoară un amplu program de decreştinare prin intermediul unei pseudo-gnoze păgâne, cu efecte dintre cele mai grave pentru spiritualitatea creştină a poporului român. Fenomenul de decreştinare s-a produs încet şi pe nesimţite. Există o convergentă cu decreştinarea deliberată, sistematică şi brutală din partea Europei. Fenomenul este complex şi se face simţit din perioada iluministă încoace. Mari personalităţi ale culturii europene încetaseră contactul cu sursele vii ale creştinismului. Una dintre manifestările acestei întreruperi o constituie însăşi diferitele încercări de raţionalizare a creştinismului. Cauzele sunt multiple, de la compromiterea creştinismului oficial prin războaiele religioase europene, până la conflictul dintre intelectuali şi cler. S-ar putea întocmi o lungă listă de gânditori şi oameni de litere care nu mai aveau nici un interes pentru idei centrale creştine si, în cazul în care aveau totuşi simt mistic (intuiţie mistică), s-au îndreptat spre alte surse de inspiraţie, orientale, francmasonice etc. În epoca noastră procesul decreştinării si-a găsit formidabili exponenţi în Freud şi Marx.

Rolul ştiinţei şi al tehnicii este foarte important când vorbim de factorii de au dus la indiferenţa religioasă a societăţii deoarece aceste domenii au pretenţia de a rezolva problemele oamenilor sau de a le oferi acestora răspunsurile căutate şi de a reprezenta o cale în satisfacerea nevoilor acestora. Oamenii au încredere în ştiinţă şi tehnică deoarece ei le percept ca fiind domeniile care ar putea să elibereze umanitatea de tot ce este rău şi să creeze o lume fericită. Prin faptul că omul are iluzia rezolvării tuturor problemelor sale, el încearcă înlăturarea lui Dumnezeu din discursul său, concepând ca inutilă latura sa spirituală.

Decreştinarea manifestată pregnant în post-modernism se manifestă în slăbirea vieţii religioase a unei părţi semnificative a

\footnotetext{
${ }^{1}$ Vezi http://ageac.org/ro/ (accessed April 11, 2016) http://samaelaunweor.ro/ (accessed April 11, 2016) https://en.wikipedia.org/wiki/Samael_Aun_Weor (accessed April 11, 2016) http://www.vopus.org/ro/ (accessed April 1, 2016)
} 
credincioşilor practicanţi până nu de mult. Acest lucru constă în participarea din ce în ce mai rar la Sfânta Liturghie şi lipsa împărtăşirii cu Sfintele Taine. Pănă nu de mult credincioşii practicanţi, loiali Bisericii formau un nucleu rezistent, chiar dacă erau în minoritate, şi aveau o viaţă creştină reală în care îmbinau rugăciunea cu milostenia.

În esenţă, climatul spiritual din Europa de azi este puternic imprimat de ateism practic, materialism şi consumism. Simultan persistă o anumită căutare de experienţă religioasă, chiar dacă într-o multiplicitate de forme, nu întotdeauna coerente între ele, care adesea conduc departe de autentica credinţă creştină. Deci, Europa contemporană se află în faţa sfidării de a face o nouă opţiune pentru Dumnezeu, dacă nu vrea să se lasă absorbită de materialism, consumism şi nonsens.

\section{Elemente gnostice în cadrul pseudo-educaţiei AGEAC}

\section{1. Psihologia revoluţionară gnostică. Repere generale}

Samael cere gnosticului - ucenic să abandoneze teoriile (adică tot sistemul educaţional actual) şi să treacă la practică, prin aceasta înţelegând intrarea după voinţa în Astral pentru a primi invăţătura direct ${ }^{2}$ de la marii instructori ${ }^{3}$.

Samael are o concepţie trihotomică cu privire la om, acesta este format din corp, suflet şi spirit. Spiritul este Infimul sau Prea înaltul din noi. Sufletul are un corp ultra-sesnibil şi material cu ajutorul căruia călătoreşte prin spaţiu. Acest corp este astral ${ }^{4}$ şi are ceva uman şi ceva divin. Corpul astral are ultrafiziologia şi ultrapatologia sa intim relaţionate cu sistemul nervos şi cu glandele

\footnotetext{
${ }^{2}$ Prin această concepţie, Samael crează de fapt un cult al misterelor de tip neopăgân, în care iniţierea de la mari maeştri este fundamentală.

3 ***Dedublarea psihică, în AGEAG, 9/2011, p. 2.

${ }^{4}$ Prin această concepţie veche a esoterismului păgân AGEAC se descoperă a fi în egală măsură şi o mişcare spiritistă având legătură cu ramurile aceteia, cu teosofia sau cu antroposofia.
} 
cu secreţie internă. Are simţuri minunate care îl ajută pe gnostic să investigheze marile mistere ale vieţii şi ale morţii. Mintea, voinţa şi conştiinţa aparţin astralului, iar gnosticul are ca scop ieşirea în corp astral, corpul fizic fiind ca o casă unde rămânem prizonieri. Samael prezintă gnoza sa ca fiind invers proporţională cu magia neagră care ştie să invoce morţii pentru a-i face vizibili şi tangibili în lumea fizică, pe când gnosticii preferă să intre ei în lumea morţilor pentru cunoaştere $^{5}$.

Ieşirea din corpul carnal se face în starea de tranziţie dintre soma şi starea de tranziţie. El susţine că a fost martor la o decorporare, ar fi văzut un nor gri, oval care ieşea prin porii întregului corp 6 .

Foarte important este să nu ne identificăm cu corpul material, să înţelegem că suntem suflete - deşi în alte conferinţe a spus că avem un suflet dar suntem spirite - altfel decorporarea devine imposibilă $\breve{7}^{7}$.

Ieşirea în astral se face cu invocarea unui mare maestru, mai precis propria Mamă Divină Particulară. Aceasta trebuie să fie invocată în numele lui Christos ${ }^{8}$. Invocarea trebuie să fie însoţită de o rugăciune. Cred în Dumnezeu, cred în Mama mea divină şi cred în Magia Albă - Mama mea, scoate-mă din corpul meu .

Un ajutor de seamă gnosticul îl poate primi de la Eliphas Levi, abatele Alfonso Luis Constant care a îmbrăţişat în perioada medievală ocultismul şi chiar satanismul ${ }^{10}$.

Samael găseşte vinovat tot sistemul educaţional actual - care absolutizează teoria în detrimentul practicii - de incapacitatea de a

$5 * * *$ Dedublarea psihică, p. 3 .

${ }^{6}$ Ibidem, p. 4.

${ }^{7}$ Ibidem, p. 5.

${ }^{8}$ Se vede clar că Samael - ca toţi ereticii de ieri şi de azi - se foloseşte de numele Mântuitorului pentru a-I atrage pe creştini, în realitate numele Christos este o mantră folosită în scopuri strict oculte.

$9 * * *$ Dedublarea psihică, p. 6-7.

${ }^{10}$ Ibidem, p. 8. 
ieşi în astral, de a vorbi cu un Maestru sau cu un Elohim. Pentru el, teoria este asimilată confuziei, prin practică înţelege exerciţiile pe care le dă discipolilor. Aceste exerciţii nu sunt decât banale mantre pe care el le tâlcuieşte cuvânt cu putere - cele mai importante ar fi Foreon, sunetul Anahot, mantra La-RA, mantra Egipto, care aduc vibraţii superioare în creier, inimă şi la nivelul organelor sexuale.

Realitatea a-gnostică în sens ocult-esoteric este o denaturare dureroasă şi o pierdere a unor capacităţi extracorporale pe care omul - deşi nu le conştientizează din cauza atrofierii memoriei - le are în calitate de iniţiat ce lucrează în Marile Temple ale Lojii Albe, în stare de inconştienţă în dimensiunea onirică ${ }^{11}$.

Fundamentală pentru demersul valorizării visului este practica Yoga visului ${ }^{12}$, ce presupune o oprire - pentru scurt moment - a procesului gândirii şi o accentuată lucrare a centrului emoţional superior. Observăm o relativizare a gândirii: forma cea mai elevată de a gândi este a nu gândi ${ }^{13}$.

Disciplina Yoga visului reprezintă începutul conversaţiei noastre cu Mama Divină ${ }^{14}$ a sufletului omenesc, conversaţie care trebuie cu necesitate să se desfăşoare în afara corpului fizic în timpul somnului ${ }^{15}$.

Mintea subconştientă îl introduce pe om în lumea fantasticului prin vis, într-o ţară a viselor. Calitatea visului este condiţionat de credinţa visătorului: dacă credem despre cineva că este bun, atunci îl visăm reprezentat ca un înger, dacă credem că e rău, îl visăm pe diavol. Subconştientul - din perspectiva lui Samael e precum un ecran ce rulează filme despre viaţa noastră internă, el

$11 * * *$ Disciplina onirică în AGEAC, 9/2011, p. 2.

12 Prin întoarcerea la tehnicilor de tip Yoga, Samael arată că sincretismul pe care-l propune nu reprezintă nimic nou sub soare, ci o reîntoarcere la elementele păgâne de tip oriental.

$13 * * *$ Disciplina onirică, p. 4.

${ }^{14}$ Prin astfel de invocări, gnoza AGEAC se vădeşte a avea o legătură puternică cu politeismul ancestral păgân.

$15 * * *$ Disciplina onirică $\breve{\text { p }}$. 5. 
acţionând fie ca un cameraman, fie ca un regizor sau operator. Cel aflat pe drumul iniţierii gnostice trebuie să îmbine exerciţiile gnostice cu esoterismul visului, pentru a fi pregătit pentru Practica intoarcerii ${ }^{16}$.

Întoarcerea se referă la reintegrarea sufletului adormit în lumea astrală, într-un univers condus de legi diferite ce ajută la trezirea Conştiinţei. Acest lucru s-a întâmplat în budismul tantric ${ }^{17}$ prin disciplina stării de somn, ce conduce la iluminarea gnosticului prin înţelegerea şi dezintegrarea viselor; în hinduism, lumea întreagă nu ar fi decât visul lui Brahma, trezirea lui Brahma înseamnă terminarea visului, iar trezirea absolută a aspirantului gnostic presupun disoluţia radicală a viselor, dar şi a resorturilor psihologice care le creează $\breve{~}^{18}$; la fel în cele 4 Evangheliii ${ }^{19}$ creştine; necesitatea trezirii este scopul principal, dar oamenii continuă să doarmă. Mântuitorului este pus pe acelaşi plan cu zeităţi mitologice inexistente precum Quetzacuatl numit Cristosul mexican care ar fi fost un om complet trezit, cu zeii sfinţi din Anahnoc, cu Talaloc zeul ploii şi al trăsnetului, etc ${ }^{20}$.

Pregătirea iniţiatică prin somn este dată de disciplina somnului Tantric ca pregătire esoterică pentru moarte ca somn final ${ }^{21}$.

Prin această pregătire se parcurg etape diverse ale Autorealizării intime ale iniţiatului, care poate să obţină perfecţiunea unor părţi izolate ale Fiinţei, a părţii celei mai elevate ale Fiinţei -

\footnotetext{
${ }^{16}$ Ibidem, p. 10.

${ }^{17}$ Trimiterea la budismul tantric este una non-sexuală în timpul iniţierii de tip A sau B. când aspirantul la gnoză ajunge în C2 (camera a doua) atunci budismul tantric I se revelează ca sex cuntinuu sau ca alchimie sexual în cuplu.

${ }^{18}$ Agregatele psihice ce susţin Ego-ul nostrum păcătos stau la baza visului şi împiedică trezirea. Imaginaţie bogată dar bolnavă !

19 Trimiterea la Evangheliile creştine este iarăşi manipulatorie pentru că interpretarea datelor acestora se face doar în cheie esoteric-ocultă.

$20 * * *$ Disciplina onirică, p. 11.

${ }^{21}$ Ibidem, p. 15.
} 
primind gradul de ismech, însă atingerea absolută a perfecţiunii a tuturor părţilor Fiinţei este aproape imposibilă ${ }^{22}$.

Omul este un punct matematic în spaţiu care serveşte drept vehicul anumitor sume de valori bune şi rele. Moartea ar fi fost o scădere de fracţii, după terminarea operaţiei matematice, singurul lucru rămas sunt valorile albe şi negre. Conform Legii Eternei Reîntoarceri, valorile se reîntorc, se reîncorporează. Noi putem verifica prin noi înşine, prin experienţă mistică directă unicul ciclu de întâmplări recurente din viaţa personală. În timpul somnului zilnic observăm repetarea operaţiei matematice a morţii. În afara corpului fizic, valorile se cufundă în lumina astrală, se atrag sau se resping în acord cu legile atracţiei şi respingerii universale. Revenirea din starea de veghe implică chiar reîntoarcerea valorilor în interiorul corpului fizic $^{23}$.

Samael îl valorizează pe Sigmund Freud, numindu-1 remarcabil medic austriac care a creat Psihanaliza, care a studiat fenomenul oniric şi l-a utilizat ca instrument terapeutic - Samael nu este de acord cu rolul visului freudian care ar fi apariţia unei dorinţe ascunse în cotloanele subconştientului uman. Samael se foloseşte de Freud pentru a justifica ştiinţific realitatea trecerii de la starea de veghe la cea de repaus şi invers, dar nu poate fi de acord că visul ca manifestare a Inteligenţei divine sau a Principiilor Inteligente ar fi instinctele sexuale reprimate din copilărie. ${ }^{24}$

Ceea ce nu a reuşit Freud, a făcut-o Karl Gustav Jung care sar fi adăpat din fântâna tradiţiilor esoterice antice. El valorizează pe Jung pentru că a recunoscut că prin vise se poate cunoaşte adevărata personalitate a fiinţ̧ei umane, pentru că a recunoscut că prin vise se pot primi mesaje cu privire la viitor. În sprijinul concepţiei sale cu

\footnotetext{
${ }^{22}$ Ibidem, p. 18.

$23 * * *$ Transcendenţa viselor, în AGEAC, 9/2011, p. 3.

${ }^{24}$ Deşi dă dovadă de crasă ipocrizie valorizând o psihanaliză eminamente atee şi materialistă cu nuanţele specifice, concluzia lui cu privire la Freud este că a avut o viziune limitată şi strâmtă cu privire la vastul universal al vizelor. (***Transcendenţa viselor, p. 4).
} 
privire la cunoaşterea viitorului cu ajutorul viselor, Samael în evocă pe Einstein, părintele teoriei relativităţii care ar fi demonstrat că orice obiect material, punându-şi în vibraţie structura atomică cu o viteză egală cu pătratul vitezei luminii, părăseşte planul fizic ca să pătrundă în cel energetic ${ }^{25}$. Einstein ar fi demonstrat de fapt existenţa unei punţi între lumea materială şi cea energetică, determinată doar de viteza sau vibraţia internă a corpurilor. El vrea să justifice ştiinţific că deasupra şi dedesubtul lumii actuale ar exista regiuni şi lumi care nu sunt fizice, dar la fel de reale precum aceasta $^{26}$.

Biblia ar valida aceste concepţii prin citarea numeroaselor pasaje onirice (ex. visele şi tălmăcirea lui Iosif) apoi Daniel în ţara Babilonului ${ }^{27}$.

Samael consideră că Egoul în timpul somnului iese din corpul fizic pentru ca corpul vital să poată reface corpul fizic. Astfel, Egoul îşi duce visele în lumile interne. În lumile interne, Egoul are acelaşi manifestări ca în lumea fizică. Întrebările pe care ni le punem în starea de veghe are ca rezultat trezirea conştiinţ̧ei ${ }^{28}$.

Există vise mecanice în care se trăieşte o relaţie cu cei cinci centri inferiori ai maşinii umane; mai există vise care sunt puse în relaţie cu cei doi centri superiori: centrul intelectual şi emoţional ${ }^{29}$.

Prin vise ne vin informaţii de la Unitatea Multiplă Perfectă cunoscută ca Dumnezeu sau zei, printr-un limbaj simbolic.

\footnotetext{
${ }^{25}$ Ibidem, p. 5.

26 Trimiterile la Freud, Yung sau Einstein nu sunt întâmplătoare ci vor să acrediteze în mintea celui racolat pretenţia ştiinţifică a gnozei lui Samael; însă ştiinţa AGEAC este una de tip piritualist şi de manifestare pe placul strict al ocultismului cu valenţe sincretiste.

$27 * * *$ Transcendenţa viselor, p. 7.

$28 * * *$ Transcendenţa viselor, p. 20.

${ }^{29}$ Ibidem, p. 24.
} 


\section{2. Omul nou ${ }^{30}$ al gnozei păgâne}

Samael propune o Revoluţie a Conştiinţei sau a Dialecticii pentru el cele două sunt identice - ce presupune o depăşire a dogmei evoluţiei, acest lucru fiind indispensabil pentru trecerea la un nivel superior al Fiinţei. În centrul acestui proces stă transformarea vieţii, care ar avea corespondent în transformările materiei, în cele de tip alchimist, dar şi cele de Evanghelie ${ }^{31}$, unde omul pământesc este comparat cu o sămânţă capabilă să germineze, germinarea presupune moartea ca o naştere spre înviere. Exemplul cel mai bun ar fi omul care este o maşină capabilă să transforme alimentele pentru subzistenţă. Prin alimente, el înţelege hrana, prana $^{32}$ care intră în om odată cu oxigenul şi impresiile - percepţii, imagine, sunet, miros, senzaţie, gust, stimul - cu care ne hrănim chiar dacă nu avem un organ pentru digestia şi transformarea $\operatorname{lor}^{33}$.

Neavând acest organ, impresiile se transformă în agregate psihice, adică în Eu-ri. De exemplu, netransformarea impresiei negative primite prin insultă, aceasta se transformă în interiorul nostru într-un Eu de răzbunare. La fel se petrece cu toate viciile. Deci noi producem Eu-ri pământeşti care se adaugă la Eu-rile din vieţile anterioare. Impresiile rănesc mintea şi declanşează în noi comportamente în sfera legii talionului - suntem loviţi, lovim ${ }^{34}$.

Samael consideră lamentabil nedigerarea şi netransformarea impresiilor, eliberarea de ele are la bază transformarea ca sacrificiu. Netransformarea lor îi face pe oameni roboţi programaţi, ca o tragedie în care Fiinţa nu se amestecă $\breve{c}^{35}$.

\footnotetext{
${ }^{30} \mathrm{Ca}$ orice manifetare dictatorial iată că şi gnoza lui Samael propune omului actual un ideal de om nou la fel ca Nietzsche sau Marx.

31 Trimiterea la Evanghelie îl arată pe Samael un diletant în materie de spiritualitate şi teologie creştină şi un manipulator al creştinilor nepracticanţi.

${ }^{32}$ Vedem lămurit componenţa păgână hindusă în cadrul gnozei AGEAC.

33 ***Transformarea impresiilor, în AGEAC, 9/2011, p. 4-5.

${ }^{34}$ Ibidem, p. 9.

${ }^{35}$ Ibidem, p. 13.
} 
Eliberarea constă în 3 aspecte: 1) învățătura eliminării agregatelor psihice; 2) renunţarea de a mai crea noi agregate; 3 ) transformarea vechilor impresii - rod al lucrării celor doi centri superiori prin autoreflexie ${ }^{36}$. Vedem că neo-gnosticul păgân este ilogic pentru că ne-a spus că nu se pot transforma întrucât nu avem organul ce poate realiza acest lucru.

Transformarea impresiilor el o denumeşte primul şoc conştient numit astfel pentru că nu se face într-o formă pur mecanică, ci prin efort autoconştient ${ }^{37}$.

\section{Gnoza păgână - întoarcerea la pseudo-spiritualitatea orientală}

În conferinţa Privind misterul, Samael vorbeşte despre legea acţiunii şi a consecinţei; fiecare om culege în această viaţă fructul propriilor acţiuni din viaţa anterioară. Această lege - nimic nou sub soarele gnostic - se numeşte karma, numită de el şi Legea Balanţei, a Compensaţiei şi a Cauzalităţii. Karma este identificată prin confuzie cu Dumnezeu şi ea are ca fundament libertatea sau liberul arbitru ${ }^{38}$.

El face o distincţie între legea karmică, a compensaţiei şi legea răzbunării sau cu determinismul sau fatalismul ${ }^{39}$.

În viziunea sa, karma este negociabilă ${ }^{40}$ - spre deosebire de celelalte curente esoterice ce le consideră implacabile - şi asta datorită Justiţiei şi Milei ce sunt două coloane principale ale Fraternităţii Albe Universale (Justiţia fără Milă = tiranie; Mila fără Justiţie = toleranţă - delict). El justifică negociabilitatea karmei pe fundamentul Milei divine (respinge viziunea autentică indiană despre

\footnotetext{
${ }^{36}$ Ibidem, p. 14.

${ }^{37}$ Ibidem, p. 16.

38 ***Legea cauzei şi a efectului, în AGEAC, 9/2011, p. 3.

${ }^{39}$ Ibidem, p. 4.

${ }^{40}$ Ca toţi întemeietorii de secte, Samael reinterpretează concepţia carmică hindusă pentru a fi mai uşor digerabilă de către occidentalul postmodern, ce se află în confuzie dar şi în cmoditate.
} 
karma ca un proces mecanic, automat şi crud) şi pe posibilitatea modificării propriului nostru destin, deoarece atunci când o lege inferioară este transcendentă de una superioară, aceasta din urmă o spală pe cea inferioară ${ }^{41}$.

Eliminarea Egoului conduce la posibilitatea iertării karmei. Legea karmei nu ar fi o lege oarbă, mai mult omul poate solicita credit Maeştrilor karmei, iar creditul se plăteşte cu fapte bune, dacă nu plătim creditul, legea karmei ne face să plătim cu durere supremă. Noi devenim conştienţi de legea karmei cu ajutorul stării de alertă noutate prin care corelăm ce ni se întâmplă cu ce am făcut în vieţile anterioare.

El crede într-un mare maestru Anubis care ar fi fost şeful Sacerdoţilor Tribunalului Karmei, ajutat de 42 de judecători ai Legii, templul lui Anubis s-ar afla în a 5-a dimensiune numită Legea Cauzală ${ }^{42}$.

În Medicina ocultă şi Magia Practică, Samael revine la negocierea karmei şi arată că aceasta este anulată când Sufletul Uman se uneşte cu Intimul. Bolile ar fi cauzate de karma - varioala este rezultatul urii, difteria este fructul fornicărilor din vieţi trecute, cancerul este de asemenea rezultatul fornicării., tuberculoza rezultatului ateismului, orbirea din naştere - rezultatul cruzimii, malaria provine din egoism iar rahitismul din materialism ${ }^{43}$.

Eliberarea ar fi opusul Naturii care are o axă mecanică formată din două legi surori: Evoluţia şi Involuţia ${ }^{44}$.

Cartea de Aur dă mărturie despre Tarot care ar fi Patronul Măsurilor. Violarea Legilor tarotului duce la pedeapsă, Legea Katanciei ar fi o Karma superioară ce ar presupune o responsabilitate a cuvintelor. Dogma Evoluţiei ar încălca legile cosmice ale

\footnotetext{
$41 * * *$ Legea cauzei şi a efectului, p. 5.

${ }^{42}$ Ibidem, p. 7.

${ }^{43}$ Ibidem, p. 14.

$44 * * *$ Transmigraţia sufletelor, în AGEAC, 9/2011, p. 2.
} 
Tarotului ${ }^{45}$ (Arcanul 10), Tarotul pentru esoterist îl fereşte de ridicol. El respinge bazele ştiinţifice ale Evoluţiei, respinge teoria lui Darwin, respingerea fiind determinată de materialismul evoluţiei ${ }^{46}$.

Respingerea Evoluţiei considerată o simplă ipoteză, are la bază realitatea proceselor distructive ale Naturii prezentate ca evoluţie şi progres. El respinge Evoluţia din cauza numărului insuficient de fapte (el în ceea ce debitează nu aduce ca demonstraţie nicio faptă $)^{47}$.

El face apel la Kali-yoga să demonstreze dificultatea din ce în ce mai mare a realizării vieţii celeste rezultată dintre moarte şi noua naştere. Cauza acestei dificultăţi îl constituie Egoul animal, esenţa fiecărei persoane fiind prinsă de Eul pluralizat. Egourile prin moarte fie se cufundă în Regnul Mineral din Lumile inferioare, fie se întorc într-un nou organism. Datorită agregatelor psihice, omul nu se reîntoarce în stadiul uman, ci în cele inferioare minerale, vegetale şi animale. Datorită egoului din sămânţa descendenţilor noştri, ne întoarcem neîncetat pentru a repeta întotdeauna aceleaşi drame şi tragedii (ilogic). Procesul evolutiv şi involutiv este trăit şi de Conştiinţă, Esenţă sau Suflet. Valuri de esenţe îşi încep evoluţia în regnul mineral, vegetal, animal şi apoi la nivel umanoid intelectual. În acord cu Legea Căderii, valuri de viaţă coboară involuând retrăind procese animale, vegetale şi minerale până in centrul de gravitate terestră. El face referire la Elementalii sau Conştiinţele elementelor, a focului, aerului, apei, pământului, nu sunt ceva fizic, ci vehicule sincere, simple şi naive cu conştiinţă $\breve{~}^{48}$. Astfel, şi ei se înscriu în Legea evoluţiei, elementalii cei mai avansaţi ai regnului mineral,

\footnotetext{
45 Avem o mostră de delir mistic. Pe de o parte Samael respinge evoluţia darwiniană pentru a fi în accord cu poziţia anti-materialistă şi anti-naturalistă pe care şi-a asumat-o pe de altă parte valorizează Tarotul şi Legile sale, ceea ce arată că gnoza lui nu este nimic decât occultism păgân antic şi medieval reactualizat.

$46 * * *$ Transmigraţia sufletelor, p. 3.

${ }^{47}$ Ibidem, p. 4.

${ }^{48}$ Dacă ar mai fi trăit am fi jurat că s-a uitat prea mult la filmul Avatar.
} 
când sunt pregătiţi fac saltul în regnul vegetal; fiecare organism vegetal este corpul fizic al unui elemental vegetal ${ }^{49}$. Tot aşa se petrece şi cu trecerea la regnul animal sau umanoid. Samael face trimitere la legea samsarei (transmigraţia sufletelor) a lui Krishna, potrivit căreia fiecărui suflet i se acordă 108 existenţe pentru Autorealizarea sa intimă ${ }^{50}$. Dacă nu se eliberează în cele 108 încercări, sufletul va coborî în Regnul Mineral scufundat involând inevitabil în măruntaiele Pământului ${ }^{51}$.

Pentru creştinismul tradiţional, infernul este un loc de pedeapsă şi de dureri eterne. Pentru cercul secret al creştinismului, pentru partea ocultă intimă sau secretă a acesteia, adică în gnoză, Infernul nu este un loc de pedeapsă eternă, ci un loc de ispăşire, purificare şi clarificare pentru Conştiinţă. El confirmă durerea din lumile infernale pentru că viaţa este destul de densă în interiorul pământului, el identifică nucleul pământului cu al nouălea cer (!), unde materia teribil de dură aduce suferinţă nepusă ${ }^{52}$. Cel care ajunge şi trece prin Involuţia scufundată a Regnului Mineral, trebuie să treacă prin ceea ce Evanghelia creştină numeşte a doua moarte. Conform Gnozei, Dumnezeu - fiind etern şi drept - nu ar putea lua de la nimeni mai mult decât datorează; astfel că pedeapsa nu e nelimitată ${ }^{53}$. În sens contrar, Dumnezeu ar fi un tiran, pentru esoterism Dumnezeu ar fi un compus format din Justiţia şi Mila divină. Sincretismul lui Samael constă că pune totul (infernul) la

$49 * * *$ Transmigraţia sufletelor, p. 8.

$50 \mathrm{Nu}$ doar legea karmei este modificată, ci maniera patologică este transformată şi legea samsarei, care nu mai are nicio legătură cu hinduismul sau budismul păgân.

$51 * * *$ Transmigrația sufletelor, p. 9.

52 Aici trebuie să recunoaştem că Samael ne-a pierdut pe toţi cei ce cu mintea întreagă ! Nu mai înţelegi nimic din amestecul acesta illogic dintre materialism grosier şi spiritualism occult.

${ }_{53}$ Trimiterea lui Dumnezeu se face de pe poziţiile ereziilor apărute în cadrul Bisericii primare cum ar fi apocatastaza dar şi într-o manieră ocultă proprie lui Samael, Dumnezeu ar fi de fapt legea cauzalităţii şi a datoriei împlinite aici şi în veşnicie. 
acelaşi nivel cu infernul lui Dante, cu al sofiştilor, cu Tartarul mitologic sau cu Avernus din politeismul roman ${ }^{54}$.

Cei ce doresc să se Autorealizezi intern cu scopul de a evita coborârea în Lumile Infernale trebuie să apuce calea Revoluţiei Conştiinţei, care îi va elibera complet şi de Legile Evoluţiei şi Involuţiei.

Samael consideră că toţi ocultiştii esoterici din trecut au dat o învăţătură incipientă, elementară, dar că mai târziu vor da umanităţii o doctrină ezoterică, superioară, de ordin transcendental. El emite pretenţia că dă acest tip de doctrină ezoterică superioară, toţi din vechime fiind doar inainte mergători ai lui ${ }^{55}$.

\section{Aspecte anti-educaţionale cu privire la conştiinţă şi coordonatele realităţii}

Trezirea conştiinţei este posibilă prin intermediul eliberării şi emancipării de dualismul mintal şi de lupta antitezelor ${ }^{56}$.

Pentru Samael, inteligenţa nu este identică cu intelectul şi nici $\mathrm{cu}$ conştientul. Conştiinţa ar fi o capacitate de cunoaştere interioară, complet independentă de orice activitate mentală. Facultatea conştiinţei este fundamentală în cunoaşterea de sine. La om - gratulat de Samael ca animal intelectual - conştiinţa doarme profund. El face o critică acerbă a psihologiei ştiinţifice care neagă existenţa conştiinţei, negarea ar fi urmarea faptului că întemeietorii acestor şcoli dorm foarte profund într-o stare de infraconştienţă şi inconştienţă ${ }^{57}$.

Conştiinţa nu trebuie confundată cu funcţiile psihologice, cu gândurile, sentimentele, cu impulsurile motorii sau cu senzaţiile. Educaţia Fundamentală - parte a psihologiei revoluţionare - are ca

\footnotetext{
$54 * * *$ Transmigraţia sufletelor, p. 11.

${ }^{55}$ Ibidem, p. 13.

56 ***Trezirea conştiinţei, în AGEAC, 9/2011, p. 2.

${ }^{57}$ Ibidem, p. 3-4.
} 
scop trezirea conştiinţei. El identifică psihologia gnostic-ocultă cu Philokalia, care ar urmări acelaşi scop. Dacă oamenii de rând au episoade de conştiinţă, întemeietorii religiilor (printre care şi Mântuitorul) au posedat Conştiinţa continuă ${ }^{58}$. Lipsa conştiinţei continue ar fi consecinţa memoriei şi a proceselor gândirii. Doar educaţia fundamentală afirmă că omul poate dobândi controlul conştiinţei şi poate obţine Autoconştiinţa ${ }^{59}$.

Faptul că avem Conştiinţa adormită este cauzat de existenţa în interiorul nostru al Eu-lui pluralizat, care ar fi Seth din mitologia egipteană, ansamblul diavolilor roşii, portretul propriilor noastre defecte. Este necesar să-l distrugem în totalitate pe Seth şi astfel ne vom reaminti vieţile anterioare şi vom putea vorbi cu zeii ! ${ }^{60}$

Samael face o apologie a lipsei de educaţie oferită de actuala societate care ar fi responsabilă - prin teoriile lor ce conduc la confuzie - de adormirea conştiinţei. El afirmă, în mod nebunesc că ar exista maeştrii ai marii Lojii Albe, adevăraţi gnostici care sunt analfabeţi însă autorealizaţi şi treziţ̧i ${ }^{61}$.

Trezirea conştiinţei dă posibilitatea studierii în timpul somnului a tuturor minunăţiilor din lumile superioare şi a convieţuirii cu marii hierofaţi ai Lojii albe şi devine astfel un iluminat. Pentru el ar exista patru stări de conştiinţă: somnul, starea de veghe, autoconştiinţa şi conştiinţa obiectivă. Starea de veghe ar fi o visare trează care ar fi permanentă, viaţa noastră nu ar fi reală ci de visare; noi trăim într-o lume a viselor şi crede cu tărie că este treaz. Cele patru Evanghelii cer trezirea dar, din nefericire, nu spun cum să ne

58 În timpul programului de autocunoaştere reprezentat de fazele A şi B, Mântuitorul este prezentat în lumini positive pentru atragerea celor ce sunt creştini. Odată cu trecerea la faza $\mathrm{C}$ şi mai ales la C2 (camera a doua) lucrurile referitoare la Mântuitorului se schimbă dramatic, El este pus alături de toţi ceilalţi întemeietori de religii şi acuzaţi că fac magie neagră.

$59 * * *$ Trezirea conştiinţei, p. 6.

${ }^{60}$ Ibidem, p. 7.

${ }^{61}$ Ibidem, p. 8. 
trezim $^{62}$. Conştientizarea adormirii înseamnă începutul trezirii şi al devenirii ca autoconştient, adică al dobândirii conştiinţei de sine. Ceilalţi esoterişti şi oculţi ar greşi fundamental considerând că toată lumea ar poseda autoconştiinţa ${ }^{63}$.

Cel care dobândeşte a patra stare de conştiinţă sau conştiinţa obiectivă devine iluminat şi poate studia lucrurile în ele însele, lumea aşa cum este ea. Ele mai sunt numite ei kasia, pistis şi nous. Identificarea cu circumstanţele îl face pe om să rămână adormit la nivelul conştiinţei.

Samael proclamă a patra dimensiune care ar conţine pământuri fermecate, regiuni din o mie şi una de nopţi. Aceasta ar fi o dimensiune superioară a spaţiului, a Cosmosului şi a vieţii ultrasensibile, pe care oamenii materialişti de azi nu le-ar accepta din amor propriu ${ }^{64}$.

Omul dacă îşi dezvoltă simţul spaţial îşi vede corpul vital lingam sharira al teosofilor, aura înţelepţilor orientali. Omul este animal intelectual cu senzaţii, percepţii şi concepte, dar mai există animalul inferior ce are doar senzaţii şi animalul superior ce are senzaţii şi percepţii ${ }^{65}$.

Samael respinge pe Zeul materie al materialiştilor, arătând că fanaticii dialecticii marxiste nu au putut să demonstreze cu adevărat existenţa materiei, dar şi ai energiei ${ }^{66}$.

Nimeni nu a văzut materia şi energia doar percepe fenomene, lucruri, forme, imagini dar nu au văzut substanţa lucrurilor. Materia ar fi un concept la fel de abstract a frumuseţea, bunătatea, curajul ${ }^{67}$.

\footnotetext{
${ }^{62}$ Samael acreditează idea că Evanghelia Mântuitorului nu ar fi absolută, ar fi limitată la nivelul cunoaşterii, de aceea ar fi nevoie de gnoza sa pentru a continua, a înţelege şi a ne mântui ca oameni prin autocunoeaştere.

$63 * * *$ Trezirea conştiinţei, p. 10.

$64 * * *$ A patra coordonată, AGEAC, 9/2011, p. 2.

${ }^{65}$ Ibidem, p. 3.

${ }^{66}$ Ibidem, p. 4.

${ }^{67}$ Ibidem, p. 5.
} 
Gnosticismul ştiinţific revoluţionar crede în existenţa multiversului ${ }^{68}$, a unei infinităţi de universuri paralele care co-există armonios. Doar aşa se pot explica faptele neclasificabile, dispariţiile misterioase. Toate grupările oculte care nu admit multiversul sunt considerate pseudo-ocultisme. Universurile paralele ar exista atât în dimensiunile superioare ale spaţiului, cât şi în cele inferioare numite infradimensiuni scufundate. Ele sunt universuri compuse din materie ca a universului nostru, nu sunt formate din anti-materie. Prin acceleratorul de protoni denumit de Samael oglindă magică s-ar fi descoperit universul paralel vecin cu noi situat în a patra dimensiune. Universurile paralele se întrepătrund reciproc fără să se confunde, având fiecare spaţiul său diferit de al nostru ${ }^{69}$.

Spaţiul este multidimensional pentru că este infinit. Tridimensionalitatea spaţiului este o proprietate a reflectării lui în Conştiinţa noastră. Omul are un simţ spaţial inferior sau superior şi vedem lumea în funcţie de planul spaţial în care ne aflăm: melcul vede lumea unidimensional, câinele bidimensional, omul ne-gnostic tridimensional iar supra-oamenii în 4, 5, 6 sau 7 dimensiuni datorită dezvoltării simţului spaţial ${ }^{70}$.

Fiecărui plan spaţial (uni, bi şi tridimensional) îi corespunde existenţa unui creier (motor-instinctiv-sexual), a două creiere (motorinstinctiv-sexual şi emoţional) sau a trei creiere (plus cel intelectual ${ }^{71}$.

El crede în apariţia navelor cosmice bazate pe fizica tetradimensională populate cu energia Solară, conduse de oameni autentici (gnostici), ce vor depăşi viteza luminii şi vor cuceri

\footnotetext{
${ }^{68}$ Aici Samael se raliază teoriei multiversului care este în vogă printer oamenii de ştiinţă materialişti şi atei. Cine să mai înţeleagă ceva !

$69 * * *$ A patra coordonată, p. 6.

${ }^{70}$ Ibidem, p. 9.

${ }^{71}$ Ibidem, p. 10.
} 
spaţiul $^{72}$. Azi, doar magii călători cu corpurile lor fizice pătrund în a patra coordonată $\breve{73}^{73}$.

A patra dimensiune este un hiperspaţiu al hipergeometriei unde există posibilitatea realizării de acte supranaturale. Experienţele gnostice au verificat existenţa celei de a patra dimensiune: levitaţiile mistice (Sfântul Ştefan al Ungariei, Dustan arhiepiscopul de Cantembury, Sfântul Ladislau al Ungariei, Sfầnta Cristina, Sfânta Izabela a Ungariei, dar şi Sfântul Toma de Aquino şi Francisc de Asisi), apoi intâmplările ginas ale unor triburi semite ascunse în interiorul pământului ce experimentau de-corporările şi Triunghiul Bermudelor care ar fi o intrare deschisă în a patra dimensiune ${ }^{74}$.

\section{Concluzii}

Pentru Samael, viaţa practică trebuie privită ca o şcoală şi nu ca un scop. Există mai multe opinii u privire la numărul drumurilor care duc la Dumnezeu; unii vorbesc de 12 drumuri (conform celor 12 constelaţii zodiacale), alţii de şapte drumuri, Iisus Hristos - cel mai mare Instructor din ultimele timpuri - vorbeşte de existenţa unui singur drum, cale.

Iisus, Marele $\mathrm{Kabir}^{75}$, a spus: Cunoaşteţi Adevărul şi el vă va face liberi. Adevărul invocat aici ar fi Marea Realitate ca izvor pur de viaţă, capabil să ne elibereze de aparenţe, relativitate sau iluzii. Acest Adevăr nu aparţine vreunei şcoli, religii, filosofii ci se află dincolo de timp şi poate fi experimentat numai prin intermediul

${ }^{72}$ Imaginaţia lui Samael nu are limite. Prin trimiterea civilizaţiei extraterestre superioare, el arată că gnoza sa se înadrează şi fenomenului UFO.

$73 * * *$ A patra coordonată, p. 11.

${ }^{74}$ Ibidem, p. 14.

75 Poetul mistic Indian Kabir din Sec XVI de profesie ţesător, reprezentat al mişcării religioase indiene Bhakti, reformator religios, sanctificat în ciuda criticilor la adresa castelor, a ritualulilor, a idolatriei dar şi al clerului hindus şi Islamic şi cel care a revendicat o spiritualitate autonomă, eliberată de ritualuri, considerat o reîncarnare a lui Iisus din Nazaret. 
deplinei manifestări a Conştiinţei divine. Doar trăirea conceptelor. Gnosticismul Universal conduce la dobândirea acelei preţioase bijuterii (Conştiinţa) şi la confundarea în oceanul Marii Realităţi. Drumul de care vorbea Mântuitorul ar fi drumul către Real al Gnosticismului Universal ${ }^{76}$.

Samael pretinde public că a ajuns la performanţa de a-şi aminti existenţele sale anterioare ${ }^{77}$. Pentru el, oamenii sunt lunari şi solari. El crede că mai devreme sau mai târziu oamenii vor fi înghiţiţi de Lună. Luna câştigă întotdeauna bătăliile cu omul, pentru că se hrăneşte cu slăbiciunile noastre. Luna este teribil de mecanicistă şi controlează umanoidul lunar care nu poate să-şi asimileze inteligenţa solară şi astfel nu reuşeşte să se transforme într-un om solar ${ }^{78}$.

$\mathrm{Cu}$ privire la viaţă, ar exista două linii în viaţă: 1) linia orizontală şi 2) cea verticală, ele formând crucea în propriul nostru interior. Orizontala începe odată cu naşterea şi se termină cu moartea. Pe cea verticală s-ar afla diferite niveluri ale Fiinţei ${ }^{79}$, cum ar fi puterile care divinizează şi ceea ce se cheamă Revoluţia Conştiinţei. Tot pe această linie se află eliberarea finală şi transformarea omului în spra-om prin eliminarea defectelor psihologice. Pe calea verticală avem posibilitatea să ne schimbăm propriul nostru nivel al Fiinţei, să săpăm de circumstanţele supăătoare ale existenţei care sunt proiecţii a ceea ce ni se întâmplă în interior ${ }^{80}$.

Dacă pentru cel mai naiv şi necatehizat AGEAC se prezintă ca o şcoală gnostică de autocunoaştere, pentru specialiştii teologi misiologi ea este o sectă deosebit de periculoasă. Există mărturii

\footnotetext{
${ }^{76}$ La fel ca toţi oculţii şi esoteriştii păgâni şi neo-păgâni, Samael îl prezintă pe Mântuitorul ca un avatar care ne-ar conduce către Dumnezeu înţeles ca o conştiinţă divină.

$77 * * *$ Drumul şi viaţa, AGEAC, 9/2011, p. 3.

${ }^{78}$ Ibidem, p. 11.

79 Pe urmele hinduismului păgân, Samael devalorizează persoana şi absolutizează Fiinţa, procesul iniţiatic al cursurilor sale fiind indispensabil pentru atingerea diferitelor niveluri ale Ființei.

$80 * * *$ Drumul şi viaţa, p. 13.
} 
cutremurătoare de la foşti adepţi care dezvălui nocivitatea acestei secte. Astfel, în realitate, AGEAC este un pseudo-cult de mistere păgân, cu trepte de iniţiere în numele auto-cunoaşterii şi autorealizării spirituale. Cursurile nu sunt altceva decât programe de manipulare contra-cost, există două faza A şi B care îl pregăteşte pe cel racolat de intrarea în fazele C (prima cameră) şi C2 (a doua cameră unde cei aflaţi vor fi mântuiţi la a doua venire a lui Samael). Toată devoţiunea la zeităţile antice, la maeştri din trecut, la personaje mitologice sau biblice, nu sunt altceva decât ritualuri demonice, astfel secta AGEAC are legături şi cu demonologia. Treptele acestuia iniţiatice nu sunt altceva decât pregătire pentru sexul sacru sau alchimia sexuală sau munca în a doua sferă. Trecerea în camera a doua se face printr-un ritual macabru de predare în mâinile Maestrului prin împuternicirea misionarului. Adeptul trebuie să recunoască că este un biet vierme al pământului, un nenorocit plin de defecte psihologice şi trebuie să accepte că mântuirea se va realiza prin sex, adică prin munca sexuală în cuplu. Prin sex continuu de 40 de ani, se pot arde cea ce numesc ego, prin sex continuu - unde femeia nu este chemată la autorealizare ci doar bărbatul, ea rămâne un simplu obiect sexual - gnosticul îşi fabrică corpul astral. În timpul partidelor de sex se cântă mantre şi sunt invocaţi îngerii lui Satana.

Sexul cu finalizare este strict interzis, la fel naşterea de copii iar iubirea nu există, ci doar patima concupisecenţei. Aşadar această sectă este una eminamente tantrică, în care abuzurile sexuale sunt considerate elemente fundamentale ale auto-realizării spirituale.

În camera a doua, adeptul află că toate religiile filosofiile, curentele spiritualiste, toate şcolile esoterice şi oculte din trecut şi prezent - în afară de AGEAC - sunt şcoli de magie neagră !

Trecerea în camera a doua presupune lepădarea de credinţă şi spiritualitatea sa. Spălarea creierului este atât de puternică, încât Samael - care a murit de cancer la 60 de ani - este prezentat ca un Christos încarnat de trei secole, auto-realizat la modul absolut, el veghează omenirea de pe un satelit al lui Jupiter, fiind unul din cei 
şapte arhangheli ai celor şapte planete din sistemul solar, fiind iluminatul prin excelenţă.

Avem aşadar un exemplu înfiorător de alternativă religioasă la adresa Bisericii, prezentată sub forma unei asociaţii gnostice nerecunoscut de statul român. Doar din aceste informaţii putem să înţelegem că secta AGEAC este de o periculozitate extremă, de o promiscuitate ce ameninţă omul şi societatea deopotrivă. În anul educaţiei creştine, evaluarea acestei secte ne va ajuta să înţelegem că lipsa dimensiunii catehetice, pedagogice şi educaţionale creştine înseamnă cu adevărat moarte duhovnicească şi pericolul pentru comunicarea veşnică cu Sfânta Treime.

\section{Bibliografie}

1. ***Dedublarea psihică în AGEAG, 9/2011

2. ***Disciplina onirică în AGEAC, 9/2011

3. ***Transcendenţa viselor, în AGEAC, 9/2011

4. ***Transformarea impresiilor, în AGEAC, 9/2011

5. ***Legea cauzei şi a efectului, în AGEAC, 9/2011

6. ***Transmigraţia sufletelor, în AGEAC, 9/2011

7. ***Trezirea conştiinţei, în AGEAC, 9/2011

8. ***A patra coordonată, AGEAC, 9/2011

9. ***Drumul şi viaţa, AGEAC, 9/2011

\section{Web sources:}

1. http://ageac.org/ro/ (accessed April 11, 2016)

2. http://samaelaunweor.ro/ (accessed April 11, 2016)

3. https://en.wikipedia.org/wiki/Samael_Aun_Weor (accessed April 11, 2016)

4. http://www.vopus.org/ro/ (accessed April 1, 2016) 